\title{
Cloud Point Extraction As a Preconcentration Step for Flame Atomic Absorption Spectrometric Determination of $\mathrm{Pb}$
}

\author{
Ersin Kilinc*, Firat Aydin, and M. Zahir Duz \\ Department of Chemistry, Faculty of Science, University of Dicle \\ TR-21280 Diyarbakir, Turkey
}

\section{INTRODUCTION}

Lead $(\mathrm{Pb})$ is an environmental toxic element that may deleteriously affect the nervous, hematopoietic, skeletal, renal, endocrine, and reproductive systems. Environmental lead pollution and its consequent health effects, particularly in children, are still a worldwide problem even after adopting so many preventive measures. The main sources of $\mathrm{Pb}$ for humans are food and water. Children are more susceptible to the effects of lead because they absorb lead more readily than adults $(1,2)$. Lead from environmental pollution is not carcinogenic, but even a low-dose $\mathrm{Pb}$ exposure has shown to have detrimental and long-lasting effects on the renal, hemopoietic, and nervous systems (3).

Since the $\mathrm{Pb}$ levels in urine, hair, water, and tissue are very low, their direct determination is not always possible and a pre-concentration step is necessary. For this purpose, various pre-concentration methods have been developed (4) which include solid phase extraction (5-9), co-precipitation (10-11), atom trap systems (12-14), flow injection-hydride generation technique for infrared spectrometry (15), solvent extraction (16-17), and cloud point extraction (18-24). Co-precipitation is a separation/ enrichment technique for trace heavy metal ions. However, this process is slow and samples sometimes have to be kept overnight for

\footnotetext{
* Corresponding author.

E-mail: ekilinc@dicle.edu.tr

Tel.: + 90-412 2488550 (ext. 3142)

Fax. + 90-412 2488039
}

\begin{abstract}
Cloud point extraction was employed as a pre-concentration method for the determination of trace amounts of lead $(\mathrm{Pb})$ after formation of a complex with (4-(2-pyridyi-azo)-resorcinol) (PAR) and later analysis by flame atomic absorption spectrometry (FAAS) using polyoxyethylene7.5 octylphenyl ether (Triton ${ }^{\circledR}$ $\mathrm{X}-114$ ) as surfactant. After phase separation, based on the cloud point separation of the mixture, the surfactant-rich phase was diluted with $1.0 \mathrm{~mol} \mathrm{~L}^{-1} \mathrm{HNO}_{3}$ in methanol. The parameters affecting the separation of the phases and the detection process were optimized. Under the optimum experimental conditions [i.e., $\mathrm{pH} 9.0,2.0^{-4} \mathrm{~L}^{-1}$ of PAR, $0.1 \%$ (w/v) Triton X-114 ] the detection limits were 2.1 and $1.6 \mathrm{ng} \mathrm{mL} \mathrm{mL}^{-1}$ for 30.0 and $40.0 \mathrm{~mL}$ solutions, respectively. The sensitivity of FAAS was improved by 31.6- and 43.7-fold for 30.0 and $40.0 \mathrm{~mL}$ of initial volumes, respectively. The developed method was applied to the determination of lead in water samples with satisfactory results. The method was validated by employing certified wastewater CWWTM-D and spiked/fortified water NWTM-15.
\end{abstract}

complete co-precipitation. Solvent extraction has been one of the most extensively studied and widely applied method in pre-concentration and separation procedures for the determination of trace elements due to its simplicity, convenience, wide scope, etc. Although this procedure is operated in batch mode, it is time-con- suming and produces large amounts of potentially toxic organic solvents as waste (4). The use of micellar systems such as cloud point extraction (CPE) has attracted considerable attention in the last few years mainly because it is in agreement with the "green chemistry" principles (25).

Cloud point extraction has been employed in analytical chemistry to separate and pre-concentrate organic compounds (26-28) and metal ions $(25,29-31)$. When aqueous solutions of nonionic or amphoteric surfactants above their critical micellar concentration (CMC) are heated at a characteristic temperature (called cloud point temperature), the solution containing the surfactant becomes turbid and separates into a surfactant-rich phase (very small viscous volume) and the remaining larger volume (bulk amount) into the diluted aqueous solution with the surfactant concentration, which is approximately equal to its critical micellar concentration. So, a high pre-concentration factor can be obtained (4). In comparison with the traditional organic liquid-liquid extraction, CPE requires a very small amount of relatively non-flammable and non-volatile surfactants. For this purpose, different nonionic surfactants such as Triton ${ }^{\circledR} \mathrm{X}-100$, Triton ${ }^{\circledR} \mathrm{X}-114$, PONPE 7.5, Tween 80 , and doubly ionic surfactants such as ammonioethylsulfates, ammoniopropylsulfates, ammoniopropansulfanates, phospobetaine, and dimethylalkylphosphine oxides have been used (28). This method permits the design of extraction schemes that are lower in toxicity and offer high efficiency. 
According to a literature survey, the combination of PAR and Triton $\mathrm{X}-114$ for the pre-concentration of $\mathrm{Pb}$ has not been applied before with cloud point extraction. In this work, a method for the cloud point pre-concentration coupled with FAAS for $\mathrm{Pb}$, using (4-(2-pyridyi-azo)resorcinol) (PAR) as complexing reagent and Triton $\mathrm{X}-114$ as surfactant, was developed. The results showed that $\mathrm{Pb}$ was determined successfully with satisfactory recoveries and precision.

\section{EXPERIMENTAL}

\section{Instrumentation}

An ATI UNICAM Model 929 flame atomic absorption spectrophotometer (equipped with an ATI UNICAM hollow cathode lamp as the radiation source) was used for the determination of lead (ATI UNICAM, USA). The FAAS experimental conditions for $\mathrm{Pb}$ are given in Table I. The $\mathrm{pH}$ was measured with a Mettler Toledo $\mathrm{pH}$ meter. A thermostated bath maintained at the desired temperature was used for the experiments and phase separation was assisted using a centrifuge in $50.0 \mathrm{~mL}$ calibrated centrifuge tubes.

\section{Reagents and Solutions}

The non-ionic surfactant Triton X-114 (Sigma Aldrich, Germany) was used without further purification. Stock standard solutions of $\mathrm{Pb}$ at a concentration of $1000 \mu \mathrm{gL}^{-1}$ were prepared from its nitrate salt. Working standard solutions were obtained by appropriate dilutions of the stock standard solutions.
A $1.10^{-2} \mathrm{~mol} \mathrm{~L}^{-1}$ solution of PAR (Fluka, Germany) was prepared by dissolving appropriate amounts of these reagents in ethanol (Merck, Germany) which were kept in a refrigerator $\left(4^{\circ} \mathrm{C}\right)$.

All other reagents were of analytical reagent grade and during all analytical work, doubly distilled water was used. The pipettes and vessels used for trace analysis were kept in dilute nitric acid at least overnight and then subsequently washed with distilled water.

$\mathrm{Na}(\mathrm{I}), \mathrm{K}(\mathrm{I}), \mathrm{Ca}(\mathrm{II})$, and $\mathrm{Mg}$ (II) solutions were prepared from their stock solutions of $1000 \mu \mathrm{g} \mathrm{mL} \mathrm{m}^{-1}$ and common anions, such as $\mathrm{Cl}^{-}, \mathrm{NO}_{3}{ }^{-}$, $\mathrm{CO}_{3}{ }^{-2}, \mathrm{PO}_{4}^{-3}$, and $\mathrm{SO}_{4}{ }^{-2}$, were prepared from their sodium salts.

CWW-TM-D and NWTM-15 were supplied from High Purity Standard, USA and LGC Standards (Middlesex, United Kingdom).

\section{Samples}

Water samples were obtained from three different sources: (a) Tap water from the laboratory was collected in 5.0-L bottles after first letting it flow for 5.0 minutes. (b) Tigris River water was collected at five different parts of the river in 1.0-L glass bottles and brought to the laboratory. Then, $0.25 \mathrm{~mL}$ of concentrated $\mathrm{HNO}_{3}$ was added to each bottle, and mixed before filtering with a $0.45-\mu \mathrm{m}$ membrane filter. (c) Effluent water was collected from an industrial region in Diyarbakır (Gözeli-Diyarbakır) and sampled like the river water in 1.0-L bottles. All of the samples were

TABLE I

Instrumental Operating Parameters for FAAS

\begin{tabular}{lr}
\hline Parameters & $\mathrm{Pb}$ \\
\hline Wavelength & $217.0 \mathrm{~nm}$ \\
Hollow cathode lamp current & $9.5 \mathrm{~mA}$ \\
Acetylene flow rate & $0.5 \mathrm{~L} \mathrm{~min}^{-1}$ \\
Air flow rate & $4.0 \mathrm{~L} \mathrm{~min}^{-1}$ \\
Slit width & $0.5 \mathrm{~nm}$ \\
\hline
\end{tabular}

immediately transferred to the laboratory and subjected to the $\mathrm{CPE}$ procedure. The $\mathrm{Pb}$ concentrations in the samples were determined by FAAS.

\section{Certified Reference Samples}

$1.0 \mathrm{~mL}$ of certified wastewater CWW-TM-D sample was diluted to $40.0 \mathrm{~mL}$ with distilled water before applying the CPE method. The CPE method was directly applied to the spiked/fortified water NWTM-15 after $\mathrm{pH}$ adjustment.

\section{Procedure}

For the cloud point extraction, $30.0-\mathrm{mL}$ aliquots of the cold solutions containing the $\mathrm{Pb}$ at the concentration of $20.0 \mathrm{ng} \mathrm{mL}^{-1}$, Triton $\mathrm{X}-1140.2 \%(\mathrm{w} / \mathrm{v})$ and $1.10^{-4} \mathrm{~mol} \mathrm{~L}^{-1}$ $\mathrm{PAR}$, adjusted to a desired $\mathrm{pH}$, were kept for 15 minutes in a thermostatic bath at $45^{\circ} \mathrm{C}$. The separation of the phases was accelerated by centrifuging at $5500 \mathrm{rpm}$ for $10 \mathrm{~min}$ utes. After cooling in an ice-bath, the surfactant-rich phases become viscous. Then, the aqueous phase was separated by inverting the tube. Subsequently, to decrease the viscosity of the surfactant-rich phase, $1.0 \mathrm{~mL}$ of $1.0 \mathrm{~mol} \mathrm{~L}^{-1} \mathrm{HNO}_{3}$ in methanol was added. Blanks were prepared with the same reagents, without the samples, undergoing an identical process. The pre-concentrated solutions were introduced into the flame by conventional aspiration.

\section{RESULTS AND DISCUSSION}

\section{Effect of $\mathbf{p H}$}

The pre-concentration of metal ions by the cloud point method involves prior formation of a complex with sufficient hydrophobicity to be extracted into the small volume of the surfactant-rich phase, thus obtaining the desired preconcentration. The extraction efficiency depends on the $\mathrm{pH}$ at which the complex formation is carried out. Thus, the effect of the $\mathrm{pH}$ on 
the extraction of $\mathrm{Pb}$ was

investigated in the $1.0-12.0 \mathrm{pH}$ range and the results are shown in Figure 1. It was found that the atomic absorbance reached maximum at about $\mathrm{pH} 9.0$, at which point maximum extraction efficiency was obtained. For this study, $\mathrm{pH} 9.0$ was optimized as the working $\mathrm{pH}$. In addition, the $\mathrm{pH}$ of all of the solutions was buffered at pH 9.0 by using a borate buffer.

\section{Effect of PAR Concentration}

The concentration of a chelating reagent has a remarkable effect on the extraction efficiency. While all other experimental parameters are constant, the effect of the optimum concentration of the chelating reagent on the recovery was studied and the results were given in Figure 2 . It can be seen that maxi- mum recovery was obtained at $2.10^{-4} \mathrm{~mol} \mathrm{~L}^{-1}$ PAR; as a result, this concentration was chosen as the optimum concentration of the chelating reagents.

\section{Effect of Triton X-114 Concen- tration}

In comparison to other surfactants, Triton $\mathrm{X}-114$ provides high density of the surfactant-rich phase as well as its appropriate cloud point temperature $\left(23-25^{\circ} \mathrm{C}\right)$ and was used for performing CPE. The variations in the analytical signals as a function of the concentration of Triton $\mathrm{X}-114$ in the range of $0.025-0.25 \%(\mathrm{w} / \mathrm{v})$ were investigated. Quantitative extraction was observed when the Triton X-114 concentration was $>0.05 \%$. Figure 3 highlights the differences observed in the analytical signals at different

\section{Atomic Apectroscopy \\ 1 Vol. 33(5), Sept./Oct. 2012}

concentrations above $0.05 \%$. The signals were decreased owing to the increase in volume and the viscosity of the surfactant phase. An amount of $0.1 \%(\mathrm{w} / \mathrm{v})$ Triton X-114 was selected to achieve the greatest analytical signals, thereby the highest extraction efficiency.

\section{Effect of Equilibration Tempera- ture and Centrifugation Time}

To optimize the method, it was also necessary to examine the effect of temperature on cloud point extraction. As a comprise between completion of extraction and efficient separation of the phases, the lowest possible equilibration temperature and the shortest incubation time were employed. The results illustrated in Figure 4 show excellent recovery for the equilibration temperature from 40 to $50{ }^{\circ} \mathrm{C}$;

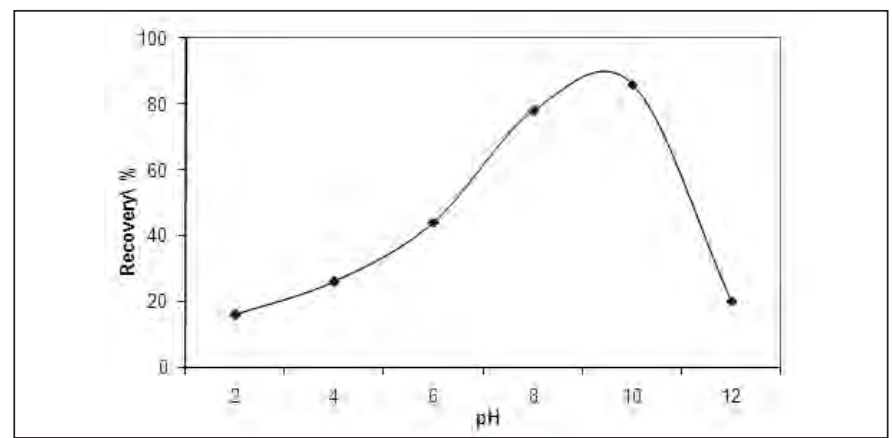

Fig. 1. Influence of the $\mathrm{pH}$ on the recovery of $\mathrm{Pb}$. Conditions: $30.0 \mathrm{~mL}$ of cold aqueous solution contain $20.0 \mathrm{ng} \mathrm{mL}^{-1} \mathrm{~Pb}$, $1.10^{-4}$ mol L $L^{-1}$ PAR, $0.2 \%(w / v)$ Triton $X-114$ at $45^{\circ} \mathrm{C}$.

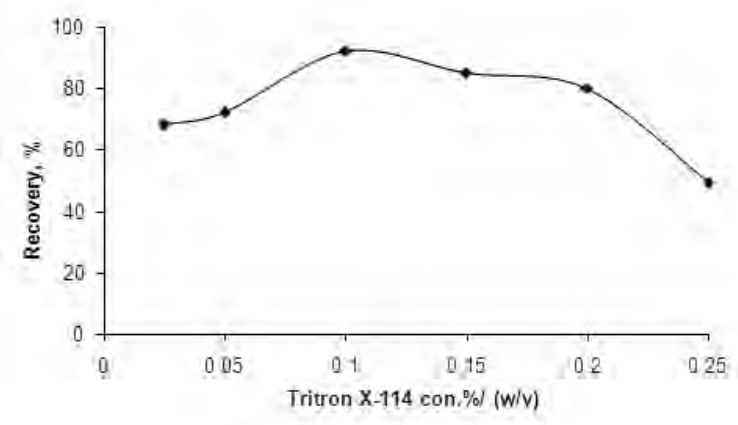

Fig. 3. Variations of the recovery of the $\mathrm{Pb}$ with Triton $\mathrm{X}-114$ concentrations. Conditions: $30.0 \mathrm{~mL}$ of cold aqueous solution, $20.0 \mathrm{ng} \mathrm{mL}^{-1} \mathrm{~Pb}, \mathrm{pH} 9.0,2.10^{-4} \mathrm{~mol} \mathrm{~L} L^{-1} \mathrm{PAR}$ at $45^{\circ} \mathrm{C}$.

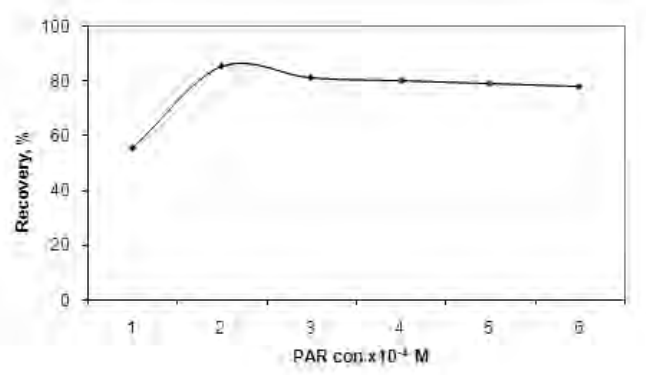

Fig. 2. Influence of the PAR concentration on the recovery of $P b$. Conditions: $30.0 \mathrm{~mL}$ of cold aqueous solution contain $20.0 \mathrm{ng} m L^{-1} \mathrm{~Pb}, \mathrm{pH} 9.0,0.2 \%(w / v)$ Triton $\mathrm{X}-114$ at $45^{\circ} \mathrm{C}$.

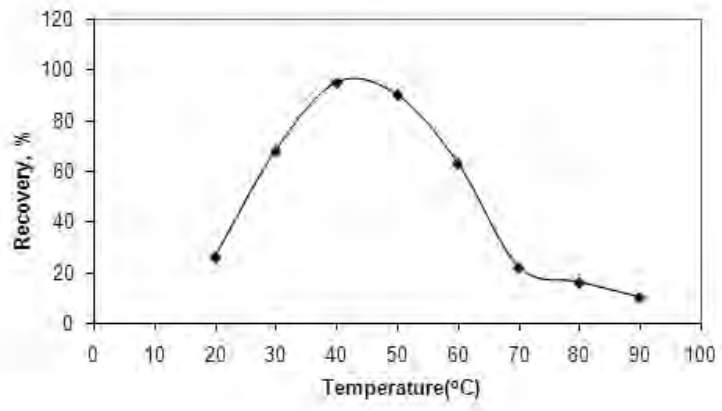

Fig. 4. Effect of the equilibration temperature on the analytical signal. Conditions: $30.0 \mathrm{~mL}$ of cold aqueous solution contain $20.0 \mathrm{ng} m L^{-1} \mathrm{~Pb}, \mathrm{pH} 9.0,2.10^{-4} \mathrm{~mol} \mathrm{~L}^{-1} \mathrm{PAR}, 0.1 \%$ Triton $X-114$ at $45^{\circ} \mathrm{C}$ 
and $45^{\circ} \mathrm{C}$ was chosen for the equilibration temperature.

The effect of centrifugation time on extraction efficiency was studied in the time range of 5.0-25.0 minutes from 3000 to $6000 \mathrm{rpm}$. A centrifugation time of 10 minutes at $5000 \mathrm{rpm}$ was selected for the entire procedure since analyte extraction in this time period is almost quantitative.

\section{Effect of Diverse Ions}

The interference of foreign ions on the determination of lead was investigated by adding a known quantity of the desired ion to a 40.0-mL aliquot of aqueous solution containing $20.0 \mathrm{ng} \mathrm{mL}^{-1}$ of lead. The tolerance limit of foreign ions was taken as the value that caused an error of not more than $\pm 5 \%$ in the absorbance. No interference was found from common cations, such as $\mathrm{Na}(\mathrm{I}), \mathrm{K}(\mathrm{I}), \mathrm{Ca}(\mathrm{II})$, and $\mathrm{Mg}$ (II), and common anions, such as $\mathrm{Cl}^{-}, \mathrm{NO}_{3}{ }^{-}, \mathrm{CO}_{3}{ }^{-2}, \mathrm{PO}_{4}^{-3}$, and $\mathrm{SO}_{4}^{-2}$, over the investigation range, which were present at concentrations of 5000 times that of lead. Similarly, the other cations tested did not cause any serious interference, even when present at concentrations 500 times that of lead.

\section{Characteristics of the Method}

A calibration curve was constructed by pre-concentrating 30.0 and $40.0 \mathrm{~mL}$ of solutions in the presence of $0.1 \%(\mathrm{w} / \mathrm{v})$ Triton $\mathrm{X}$ 114 at $\mathrm{pH} 9.0$ and under the other experimental conditions specified in the procedure. The samples were introduced into the flame following the addition of $1.0 \mathrm{ml}$ of $1.0 \mathrm{~mol} \mathrm{~L}^{-1} \mathrm{HNO}_{3}$ in methanol. In this case, linear relationships between the absorbance measured and the concentration of the metal placed in solutions were obtained. Table II lists the parameters of the calibration curves, the relative standard deviations obtained for 3 replicates subjected to the complete procedure, and the detection limits. Table II also gives the calibrations obtained with standard solutions of $\mathrm{Pb}$ not subjected to the pre-concentration step.

The linear calibration range of the method was obtained as $10.0-30.0 \mathrm{ng} \mathrm{mL}^{-1}$ for $30.0 \mathrm{~mL}$ of initial solutions and 5.0-25.0 $\mathrm{ng} \mathrm{mL}^{-1}$ for $40.0 \mathrm{~mL}$ of initial solutions. The limit of detection (LOD) was found to be $2.1 \mathrm{ng} \mathrm{mL}^{-1}$ and $1.6 \mathrm{ng} \mathrm{mL}^{-1}$ for 30 and $40 \mathrm{~mL}$ of solutions, respectively. The enhancement factor was calculated as 31.6 and 43.7 for 30.0 and $40.0 \mathrm{~mL}$ of solutions, respectively.

The LOD values obtained from our study were compared with studies published in the literarure. 1-phenylthiosemicarbazide (32), ammonium pyrrolidinedithiocarbamate (APDC) and diethyldithiocarbamate (DDTC) (33),
3-(1-(1-HIndol-3-Y1)-3-phenylallyl)1H-indole (34), bis ((1H-benzo(d) imidazol-2yl)ethyl) sulfane (35), brillant cresyl blue (18), APDC (36), and 3-((4-bromophenyl) (1-H-inden3-yl)methyl)-1 H-indene (37) were used as complexation reagent for $\mathrm{Pb}$. The LOD values were in the range of $1.14-7.5 \mathrm{ng} \mathrm{mL}^{-1}$ (18, 32-37). Therefore, it could be said that our method gave comparable LODs and low levels of $\mathrm{Pb}$ can be determined by this method.

\section{Application of Method to Water Samples}

Before application of this method to real samples, it was applied to certified reference water samples. The accuracy of the method was tested using certified reference materials wastewater CWW-TM-D and spiked/fortified water NWTM-15. $40.0 \mathrm{~mL}$ of certified water samples (CWW-TM-D diluted by 40.0 times) were subjected to the CPE method to determine its $\mathrm{Pb}$ content. No digestion procedure was applied to the samples. The results showed that the found values agreed with the certified values. The relative standard deviations were found to be lower than 2.1\% (see Table III).

The $\mathrm{Pb}$ concentrations in several liquid samples were determined by the developed CPE procedure. When the samples were collected, they were immediately filtered

TABLE II

Analytical Characteristic of the Method

\begin{tabular}{|c|c|c|c|c|c|c|c|}
\hline Conditions & $\begin{array}{l}\text { Concentration } \\
\text { Range }\left(\mathrm{ng} \mathrm{mL} \mathrm{m}^{-1}\right)\end{array}$ & Slope $^{\mathrm{a}}$ & Intercept & $\mathbf{r}^{2}$ & (\%) RSD & $\begin{array}{l}\mathrm{LOD}^{\mathrm{b}} \\
(\mathrm{n}=3)\end{array}$ & $\mathrm{E}^{\mathrm{C}}$ \\
\hline Without pre-concentration & $250.0-1000.0$ & 0.038 & 1.0 & 0.9974 & $2.4\left(750.0 \mathrm{ng} \mathrm{mL}^{-1}\right)$ & 65 & 1 \\
\hline With pre-concentrationd & $10.0-50.0$ & 1.20 & -0.4 & 0.9978 & $3.2\left(25.0 \mathrm{ng} \mathrm{mL}^{-1}\right)$ & 2.1 & 31.6 \\
\hline With pre-concentratione & $5.0-25.0$ & 1.66 & -0.3 & 0.9938 & $2.8\left(15.0 \mathrm{ng} \mathrm{mL}^{-1}\right)$ & 1.6 & 43.7 \\
\hline
\end{tabular}




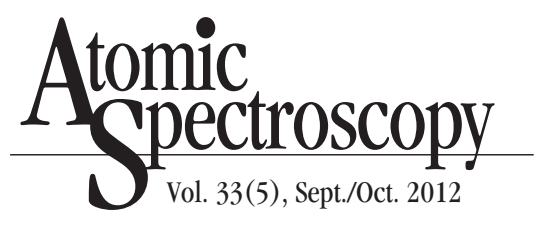

TABLE III

Determination of Lead in

Certified Reference Samples

\begin{tabular}{lccc}
\hline $\begin{array}{l}\text { Reference } \\
\text { Sample }\end{array}$ & Certified & Measured & $\begin{array}{l}\text { RSD } \\
(\%)\end{array}$ \\
\hline CWW-TM-D $^{\mathrm{a}}$ & $1.0 \mu \mathrm{g} \mathrm{mL}^{-1}$ & $0.96 \pm 0.02 \mu \mathrm{gL}^{-1}$ & 2.1 \\
NWTM-15 & $11.8 \mathrm{ng} \mathrm{mL}^{-1}$ & $11.3 \pm 0.1 \mathrm{ng} \mathrm{mL}^{-1}$ & 0.9 \\
\hline
\end{tabular}

${ }^{a}$ It was diluted by 40.0 times.

TABLE IV

Determination of Lead in Liquid Food Samples

\begin{tabular}{lcll}
\hline Sample & $\begin{array}{c}\text { Added } \\
\left(\mathrm{ng} \mathrm{mL}^{-1}\right)\end{array}$ & $\begin{array}{c}\text { Found } \\
\left(\mathrm{ng} \mathrm{mL}^{-1}\right)\end{array}$ & $\begin{array}{c}\text { RSD } \\
(\%)(\mathrm{n}=3)\end{array}$ \\
\hline Tap Water & - & - & - \\
Tigris River Water & 10.0 & $10.2 \pm 0.2$ & 2.0 \\
Effluent Water & - & - & - \\
& 10.0 & $9.7 \pm 0.2$ & 2.1 \\
& 10.0 & $8.3 \pm 0.2$ & 2.4 \\
& & $17.8 \pm 0.3$ & 1.7 \\
\hline
\end{tabular}

approach in the monitoring of $\mathrm{Pb}$ in different samples at low cost with simplicity and efficiency. The proposed CPE method gives low LOD and RSD values and offers solvent-free extraction of $\mathrm{Pb}$ from its initial matrix.

Received May 22, 2912.

\section{REFERENCES}

1. O.P. Soldin, B. Hanak and S.J. Soldin, Clin. Chim. Acta 327, 109 (2003).

2. M Ahamed, S. Singh, J.R. Behari, A. Kumar and M.K.J. Siddigui, Clin. Chim Acta 377, 92 (2007).

3. R. Fertmann, S. Hentschel, D. Dengler, U. Janben and A. Lommel, Int. J. Hyg. Envir. Heal. 207, 235 (2004).

4. M.G.A. Korn, J.B. Andrade, D.S. Jesus, V.A. Lemos, M.L.S.F. Bandeira, W.N.L. Santos, M.A. Bezerra, F.A.C. Amorim, A.S. Souza and S.L.C. Ferreira, Talanta 69, 16 (2006).

5. S. Wang and R. Zhang, Anal. Chim. Acta 575, 166 (2006).

6. Z. Wan, Z. Xu and J. Wang, Analyst 131, 141 (2006).

7. P. Hashemi, H. Hassanvand, $H$. Naeimi and A.R. Ghiasvand, Microchim. Acta 150, 147 (2005).

8. Y. Akama, K. Yamada and O. Itoh, Anal. Chim. Acta 485, 19 (2003).
9. Y. Petit Peña, B. Paredes, W. Rondón, M. Burguera, J.Luis Burguera, C. Rondón, P. Carrero and T. Capote, Talanta 64, 1351 (2004).

10. H. Chen, J. Jin and Y. Wang, Anal. Chim. Acta 353, 181 (1997).

11. M. Soylak, S. Saracoglu, U. Divrikli, and L. Elci, Talanta 66, 1098 (2005).

12. D.K. Korkmaz, N. Ertas and O.Y. Ataman, Spectrochim. Acta B 57, 571 (2002).

13. H. Matusiewicz, Spectrochim. Acta B, 52, 1711 (1997).

14. H. Matusiewicz and M. Krawczyk, Microchem. J. 83, 17 (2006).

15. O. Cankur, D. Korkmaz and O.Y. Ataman, Talanta 66, 789 (2005).

16. E. Carasek, J.W. Tonjes and M. Scharf, Talanta 56, 185 (2002).

17. J.H. Wang and E.H. Hansen, J. Anal. At. Spectrom. 17, 1284 (2002).

18. Y. Surme, I. Narin, M. Soylak, H. Yuruk and M. Dogan, Microchim Acta 157, 293 (2007).

19. O.M. Luconi, M.F. Silva, R.A. Olsina and L.P. Fernandez, Talanta 51, 123 (2000).

20. D.L.G. Borges, M.A.M.S. Veiga, V.L.A. Frescura and A.J. Curtius, J. Anal. At. Spectrom. 18, 501 (2003).

21. T.A. Maranhao, D.L.G. Borges, M.A.M.S. Veiga and A.J. Curtius, Spectrochim. Acta B 60, 667 (2005).

22. O.M. Luconi, A.R. Olsina, L.P. Fernandez and M.F. Silva, J. Hazard. Mater. 128, 240 (2006). proposed method allowed the determination of $\mathrm{Pb}$ at $\mathrm{ng} \mathrm{mL}^{-1} \mathrm{lev}$ els. Thus, it represents a promising 
23. J.L. Manzoori and A.B. Tabrizi, Anal. Chim. Acta 470, 215 (2002).

24. M.A.M. Silva, V.L.A. Frescura and A.J. Curtius, Spectrochim. Acta B 55,803 (2000).

25. M.A. Bezerra, M.A.Z. Arruda and S.L.C. Ferreira, Appl. Spectrosc. Rev. 40, 269 (2005).

26. Z.S. Ferrera, C.P. Sanz, C.M. Santana, J.J.S. Rodriguez, TRAC-Trend. Anal. Chem. 23, 469-479 (2004).

27. S. Rubio and D.P. Bendito, TRACTrend. Anal. Chem. 22, 470-485 (2003).

28. R.C. Martinez, E.R. Gonzalo, B.M. Cordero, J.L.P. Pavon, C.G. Pinto and E.F. Laespaada, J. Chromatogr. A 902, 251 (2000).

29. E.K. Paleologos, D.L. Giokas and M.I. Karayannis, TRAC-Trend. Anal. Chem. 24, 426 (2005).

30. E. Kilinc, A. Çetin, M. Toğrul and H. Hoşgören, Anal. Sci. 24, 763 (2008).

31. E. Kilinc, V. Lepane, A. Viitak and B. Gumgum, Proc. Eston. Acad. Sci.58, 190 (2009)

32. D. Citak and M. Tuzen, Food Chem Toxicol. 48, 1399 (2010).

33. F. Shah, T.G. Kazi, H.I. Afridi, M.B. Arain and J.A. Baig, J. Hazard. Mater. 192, 1132-1139 (2011).

34. M. Ghaedi, K. Nikman and M. Soylak, Pak. J. Anal. Environ. Chem. 12, 42 (2011).

35. M. Ghaedi, A. Shokrollahi, K. Niknam, E. Niknam, A .Najibi and M. Soylak, J. Hazard. Mater. 168, 1022 (2009).

36. H. Han, Y. Xu and C. Zhang, Commun. Soil Sci. Plan. 42, 1739 (2011).

37. M. Ghaedi, H. Tavallali, A. Shokrollahi, M. Zahedi, K. Niknam and M. Soylak, Clean-Soil Air Water 37, 328 (2009). 